\title{
VINCULAÇÃO E DISCRICIONARIEDADE NOS ATOS ADMINISTRATIVOS
}

\author{
VLADIMIR DA ROCHA FRANÇA*
}

1. Dever-poder discricionário no regime jurídico-administrativo - 2 . Elementos dos atos administrativos - 3. Mérito do ato administrativo 4. O problema dos "conceitos jurídicos indeterminados" - 5. Consideraçōes finais

\section{Dever-poder discricionário no regime jurídico-administrativo}

A lei estabelece as competências que permitirão aos agentes públicos desempenhar as funções e observar os fins que a mesma contém. Dentro dessas competências, caberão aos agentes públicos atuar no sentido de satisfazer os interesses da coletividade de forma concreta e efetiva.

Quando as circunstâncias e a matéria tratada permitem, a lei procura prever com maior precisão possível as necessidades e problemas com os quais se depararão o agente público. Tenta ainda impor o comportamento que este deve manter, assim como as soluções que devem ser escolhidas.

Todavia, decorre dos preceitos que norteiam o Estado de Direito o princípio de que as normas integrantes do sistema jurídico devem pugnar por conceitos gerais e abstratos, haja vista a repulsa à exceção, ao favoritismo, às perseguições e à tutela de interesses individuais em detrimento aos interesses da coletividade.

O legislador é incapaz de apresentar normas que em seu seio estejam presentes todos os elementos de fato dos problemas enfrentados pela administração pública. E, causa temeridade à sociedade que se estabeleça normas por demais específicas, enfim, riscos aos direitos e garantias individuais e da própria coletividade.

Portanto, se a lei pode definir comandos específicos, sem que isso ameace os princípios básicos do Estado de Direito, assim o fará. Caso a instituição dessas diretivas se mostrem possivelmente danosas ao interesse público ou insuficientes

* Mestre em Direito Público pela UFPE; Doutorando em Direito do Estado pela PUC/SP.

R. Dir. Adm..

Rio de Janeiro, 222: 97-116, out./dez. 2000 
para a sua satisfação, caberá à lei criar o necessário espaço à administração pública poder atuar com eficiência ${ }^{1}$.

No âmbito do regime jurídico-administrativo, o dever-poder discricionário consiste na prerrogativa concedida pelo ordenamento jurídico à administração pública, de modo implícito ou explícito, para a prática de atos administrativos, com liberdade na escolha de sua conveniência, oportunidade e conteúdo ${ }^{2}$

Existindo espaço para o administrador em optar por um comportamento adequado à resolução do problema posto, ou melhor, para fazer uma apreciação subjetiva do caso concreto, sustentado por critérios de conveniência e oportunidade, há discricionariedade.

O espaço para o emprego do juízo de oportunidade pela administração publica somente é admitido se houver uma norma jurídica que lhe confira tal poder. Em face das imposições do princípio da legalidade administrativa, o dever-poder discriconário deve estar previsto em lei ou pela própria Constituição em vigor. Todos os instrumentos de ação administrativa tributam sua existência ao ordernamento juridico. Se este não o estabelecer, não há dever-poder discricionário.

As omissões legislativas nem sempre implicam em dever-poder discricionário. Se disserem respeito a algum elemento do processo de formação do ato administrativo material, há espaço para a utilização do juízo de oportunidade na ação administrativa. A Administração não cria instrumentos através do dever-poder discricionário, mas sim do dever-poder regulamentar, meio adequado para a integração e concretização do regime jurídico-administrativo.

Nesse caso, não estaremos diante de discricionariedade administrativa, mas sim de discricionariedade legislativa no âmbito da Administração. O espaço de discricionariedade no bojo do dever-poder regulamentar variará consoante o estabelecido na lei, ato legislativo material que lhe é indiscutivelmente superior (a Constituição rejeito os regulamentos autônomos). Mas não deixa de ser uma discricionariedade diversa da administrativa, mais ampla, mais profunda, haja vista lidar não com a constituição de preceitos individuais e concretos, mas sim, com a de preceitos genéricos e abstratos.

A lei institui a discricionariedade quando verifica que a administração pública, mais próxima dos problemas por ela enfrentados, evidentemente, mostra-se melhor preparada para tomar as decisões e escolhas mais adequadas ao uso concreto.

Também sua existência fica, necessariamente, na dependência, a nosso ver, das circunstâncias do caso concreto, onde o interesse público se torna mais visível. Como instrumento da ação administrativa, o dever-poder discricionário está subordinado ao interesse público, sua razão ideológica de ser. A opção da administração deve ser a melhor, a que melhor supra o interesse público na situação jurídica subjetiva. É uma obrigação oriunda do princípio constitucional da eficiência.

1 Hely Lopes Meirelles, Direito Administrativo Brasileiro, 20 ed., atualizada por Eurico de Andrade Azevedo et al, São Paulo, Malheiros, 1995, pp. 103-104.

2 Idem, Ibidem, p. 102. 
Se há dúvida quanto à melhor solução, há espaço para o emprego do juízo de oportunidade pelo administrador. Caso contrário, a eficiência administrativa, conjugada com os demais princípios constitucionais, desconstitui in concreto o que a norma abstratamente admitiu.

Se o caso concreto, assim permitindo as circunstâncias e o próprio ordenamento jurídico, admitir mais de uma decisão, confirma-se o espaço que a lei abstratamente admitiu.

Para identificarmos a zona da discricionariedade no ato administrativo, é preciso antes definir seus elementos. $O$ modo de como a lei os define determinará a possibilidade do emprego ou não do juízo de oportunidade na concretização do regime jurídico-administrativo pela norma individual e específica que tradicionalmente vem se denominando ato administrativo.

\section{Elementos dos atos administrativos}

Ato administrativo material consiste em uma norma jurídica, individual e concreta, expedida pela administração pública (ou por quem detiver competência administrativa), que se destina à formação e determinação das situações jurídicas subjetivas que serão regradas pelo regime jurídico-administrativo. Destina-se a constituir, modificar, extinguir ou reconhecer uma relação jurídica de direito administrativo, a ser regida por esse sistema de princípios e regras de direito.

O desenvolvimento da atividade administrativa é uma sucessão de atos e fatos jurídico-administrativos, onde se busca a concretização do interesse público tutelado pela norma de direito administrativo positivo.

Fato jurídico-administrativo compreende toda e qualquer ocorrência, social ou física, reconhecida pelo regime jurídico-administrativo como geradora de efeitos jurídicos. $\mathrm{O}$ ato administrativo também é um fato jurídico, que difere dos demais por representar uma norma jurídica, que passa a integrar o regime jurídico-administrativo a partir de sua existência material.

Embora não haja unanimidade na doutrina, no que concerne a questões terminológicas, os atos administrativos são formados por cinco elementos: competência, motivo, objeto, forma, e finalidade.

A competência consiste na atribuição legal de deveres-poderes para o desempenho da função estatal, o impulso gerador do ato ${ }^{3}$. A regra de competência define o órgão ou agente público habilitado para produzir o ato administrativo ${ }^{4}$.

3 Hely Lopes Meirelles, op. cit., p. 134; e Miguel Seabra Fagundes, $O$ Controle dos Atos Administrativos pelo Poder Judiciário, 6 ed., São Paulo, Saraiva, 1984, p. 23.

4 Cf. Celso Antônio Bandeira de Mello, Curso de Direito Administrativo, 5 ed., São Paulo, Malheiros, 1994, pp. 178-179; Caio Tacito, "Ato e Fato Administrativo", in: Temas de Direito Público (Estudos e Pareceres), $1^{\circ}$ Vol., Rio de Janeiro, Renovar, 1997, p. 299; e José Cretella Júnior, $O$ "Desvio de Poder" na Administração Pública, 4 ed., Rio de Janeiro, Forense, 1997, p. 35. 
O motivo compreende os pressupostos fáticos e jurídicos que autorizam a edição e concretização do ato ${ }^{5}$. Subdivide-se em motivo material e motivo legal.

O motivo material é a situação jurídica subjetiva que ensejou a expedição do ato administrativo. Já o motivo legal, advém da previsão legal abstrata do fato jurídico-administrativo ${ }^{6}$.

O motivo não se confunde com a motivação, pois esta compreende a exteriorização daquele. Na motivação, expõe-se a regra de direito que habilita a ação administrativa concreta (motivo legal), a situação jurídica subjetiva que serviu de base para a decisão (motivo material), bem como a enunciação da relação de pertinência lógica entre o motivo material e o motivo legal?

O objeto corresponde ao conteúdo do ato administrativo, isto é, "a criação, modificação, ou comprovação de situações jurídicas concernentes a pessoas, coisas ou atividades sujeitas à ação do Poder Público"§, ou, como prefere José Cretella Júnior", "efeito prático na ordem administrativa que o sujeito pretende alcançar mediante ação direta ou indireta".

A forma representa o revestimento exterior do ato administrativo ${ }^{10}$, através do qual o ato administrativo ingressa no ordenamento jurídico.

A finalidade representa o interesse público específico a ser atingido ou tutelado com a edição e concretização do ato administrativo, "o resultado prático que se procura alcançar pela modificação trazida à ordem jurídica" ", ou, nas precisas palavras de Caio Tácito ${ }^{12}$.

“(...) é o sentido teleológico do ato, é o objetivo jurídico material a que se dirige, em última análise, a ação administrativa".

Como bem leciona José Cretella Júnior ${ }^{13}$ :

“No ato, parte-se do motivo. passa-se pelo objeto, para atingir-se determinado fim".

Os elementos do ato administrativo serão construídos, no caso da discricionariedade administrativa, pela convivência do juízo de juridicidade com o juízo de oportunidade do administrador.

5 Cf. Hely Lopes Meirelles, op. cit., p. 136; Miguel Seabra Fagundes, op. cit., p. 23; Celso Antônio Bandeira de Mello, op. cit., p. 179; e José Cretella Júnior, op. cit., p. 36.

6 Celso Antônio Bandeira de Mello, op. cit., pp. 179-180.

7 Cf. Celso Antônio Bandeira de Mello, op. cit., pp. 181-182.

8 Hely Lopes Meirelles, op. cit., p. 137. Cf. Miguel Seabra Fagundes, op. cit., p. 23.

9 Op. cit., p. 35.

10 Cf. Hely Lopes Meirelles, op. cit., p. 135; Miguel Seabra Fagundes, op. cit., p. 24; e José Cretella Júnior, op. cit., p. 36.

11 Miguel Seabra Fagundes, op. cit., p. 23.

12 Caio Tácito, op. cit., p. 301.

13 José Cretella Júnior, op. cit., p. 38 (grifo no original). 


\section{Mérito do ato administrativo}

A ordem jurídica constitui a fonte dos poderes administrativos. Tanto pode esgotar todas as condições de seu exercício como remeter a apreciação subjetiva da Administração. A distinção das formas de atribuição legal dos poderes administrativos corresponde aos conceitos de vinculação e discricionariedade. A distinção entre atos vinculados e atos discricionários representa um ponto significativo na questão do poder discricionário.

Nos atos vinculados, a lei constrói o ato administrativo com todas as especificações necessárias a sua aplicação, devendo o administrador ater-se ao seu enunciado e aos requisitos e elementos indispensáveis a plena eficácia jurídica da medida prevista, sob pena de invalidade, pois:

"A legalidade do ato administrativo, cujo controle cabe ao Poder Judiciário, compreende não só a competência para a prática do ato e de suas formalidades extrínsecas, como também de direito e de fato, desde que tais elementos estejam definidos em lei como vinculadores do ato administrativo" 14 .

Todo o ato administrativo tem um mínimo de vinculação. A lei não abdica de indicar a competência, a forma e nem a finalidade dos atos administrativos materiais. Mas também é difícil um ato inteiramente vinculado ${ }^{15}$

Só há uma escolha para o agente público, quando investido no poder vinculado: a que a lei objetivamente determinar, e tipificada de modo a não causar qualquer dúvida ou controvérsia na concretização da lei. Predominam as especificações da norma jurídica sobre os elementos deixados livres aos agentes públicos.

O administrador tem o poder discricionário na medida do disposto em lei, restrito naqueles elementos deixados livres pela mesma. A administração pública está incondicionalmente a ela subordinado, devendo observar no exercício do poder discricionário o mínimo de juridicicidade, e o interesse público ${ }^{16}$. As prerrogativas discricionárias estão sujeitas à mensuração imposta pela lei. A remissão legal ao juizo subjetivo do administrador não pode ser mais do que parcial, e não total:

"En efecto, si resulta que el poder es discrecional en cuanto que es atribuido como tal por la Ley a la Administración, resulta que esa Ley há tenido que configurar necessariamente varios elementos dicha potestad y que la discrecionalidad, entendida como libertad de apreciación por la Administración, sólo puede referirse a algunos elementos, nunca a todos, de tal potestad" "1".

14 Hely Lopes Meirelles, op. cit., p. 102.

15 Eduardo Garcia de Enterria \& Tomás-Ramón Fernandez. Curso de Derecho Administrativo, 8 ed., Vol. I, Madrid, Civitas, 1998, pp. 446-447; e Hely Lopes Meirelles, op. cit., p. 102.

16 Themístocles Brandão Cavalcanti, “Do Poder Discricionário”, in: Revista de Direito Administrativo, Seleção Histórica, pp. 436-437.

17 Eduardo Gárcia de Enterria \& Tomás-Ramón Fernandez, op. cit., p. 446. 
A discricionariedade não se confunde com arbitrariedade. Nesta o poder público exorbita a esfera de sua competência e utiliza-se de instrumento proibidos ou inadequados no cumprimento da finalidade legal, ou mesmo, ignora-a seguindo finalidades estranhas ao interesse público. O exercício do poder discricionário pressupõe a severa obediência aos parâmetros legais e a correta subsunção do caso concreto às categorias impostas pela lei. Seria uma incoerência se o Estado de Direito edificasse um poder, um instrumento, sem limites e, danoso ao ordenamento jurídico, para a administração pública.

E bem lembra José Cretella Júnior ${ }^{18}$ :

"Denomina-se discrição a faculdade outorgada ao agente público de decidir ou deixar de decidir dentro do âmbito demarcado pela norma jurídica, entendendo-se por arbítrio a faculdade de operar sem qualquer limite, em todos os sentidos, com inobservância de qualquer norma de direito".

A competência é sempre um elemento vinculado nos atos administrativos, objetivamente fixado pelo legislador. Não seria concebível, no Estado de Direito, a atribuição de prerrogativas e objetivos à administração pública sem a precedência da lei ${ }^{19}$.

A forma não enseja apreciação discricionária, pois ao contrário do direito privado, onde esse elemento é deixado à autonomia da vontade do particular (quando a lei não prescreve nenhum), no direito administrativo, a forma usualmente é predeterminada pela lei. Não cabe à administração pública criar forma através da discricionariedade administrativa, mas pode fazê-lo pelo exercício da atividade legislativa que the foi conferida com o reconhecimento legal do poder regulamentar.

Celso Antônio Bandeira de Mello ${ }^{21}$ e Weida Zancaner ${ }^{21}$, colocam a forma, junto ao conteúdo (ou objeto). como elemento do ato administrativo, ambos condicionando a sua existência. Esses juristas separaram-na da formalização, que seria o pressuposto formalístico do ato administrativo, que indicaria o modo específico que a lei impõe para a exteriorização do mesmo. Este seria um dos elementos que determinaria a validade.

A distância entre a forma do ato e a forma legal pode ou não levar à invalidade, dependendo de sua relevância para a garantia do administrado. Se não houver prejuízo à esfera de direitos do cidadão, o ato administrativo viciado em sua houver prejuízo à esfera de direitos do cidadão, o ato administrativo viciado em sua forma pode ser convalidado. Mas isso não significa dizer que haja espaço discricionário na exteriorização do ato administrativo, pois a convalidação é um meio juridica-

18 Op. cit., p. 52.

19 Caio Tácito, "Abuso de Poder Administrativo no Brasil", in: Temas de Direito Público (Estudos e Pareceres), $1^{\circ}$ Vol.. Rio de Janeiro, Renovar, 1997, p. 51.

20 Op. cit., pp. 189-190.

21 Em seu Da Convalidação e da Invalidação dos Atos Administrativos, 2 ed., São Paulo, Malheiros, 1993, p. 34. 
mente aceito para a restauração da juridicidade do ato administrativo. Não há discricionariedade administrativa na quebra consciente de um requisito de validade.

Quanto à finalidade, a matéria é controvertida.

Parcela da doutrina aceita a influência de juízo de oportunidade na apreciação da finalidade. Poderia haver, o emprego desse critério na qualificação do interesse público, embora este sempre constitua elemento vinculado 22 .

Caberia o juízo de oportunidade no fim imediato e específico do ato administrativo, desde que corroborasse o fim genérico expresso na lei ${ }^{23}$.

Comentando o voto do jurista Miguel Seabra Fagundes, em acórdão proferido na ap. Cível $n^{\circ} 1.422$ pelo Tribunal de Justiça do Rio Grande do Norte, Victor Nunes Leal $^{24}$ expõe a posição do administrativista potiguar: "Entretanto, segundo esclarece o des. Seabra Fagundes, apoiado nos melhores autores, 'no que concerne à competência, à finalidade e à forma, o ato discricionário está tão sujeito aos textos legais como qualquer outro'. Quanto à finalidade dos atos administrativos (discricionários ou vinculados), está ela sempre expressa ou implícita na lei; por isso mesmo, o fim legal, que é necessariamente um fim de interesse público, também constitui aspecto vinculado dos atos discricionários, susceptíveis, portanto, de apreciação jurisdicional".

Quanto aos atos administrativos materiais, não se pode falar efetivamente numa apreciação discricionária da finalidade legal, se ela foi univocamente expressa no texto legal, esgotando a formação do juízo de oportunidade. Já em se tratando de um fim político-econômico posto no texto normativo, a questão se torna mais complexa.

Podem estar obrigados nos atos administrativos, tanto formais quanto materiais fins relacionados com a política econômica do Estado. Nos atos administrativos materiais, a competência, forma e finalidade permanecem vinculadas, sendo vedada a apreciação subjetiva do administrador do que foi politicamente esgotado pelo legislador ou pela própria Administração, quando aqueles desencadeiam a concretização normativa do ato administrativo dotado de força de lei material.

Já nos atos administrativos formais com conteúdo legislativo, há espaço para o emprego de juízo de oportunidade quanto à finalidade específica ou imediata. A discricionariedade legislativa constitui um processo de integração entre as demandas sociais, políticas e econômicas, e o sistema de direito positivo, garantindo sua efetividade social. Ao legislador compete qualificar o interesse público contido no preceito constitucional, como ao administrador-legislador, ao mensurar o interesse público contido na lei. Na legislação, juridiciza-se o fato social.

$\mathrm{Na}$ discricionariedade administrativa é inadmissível questionar ou mensurar o interesse público contido no preceito legal através do juizo de oportunidade, de

22 Celso Antônio Bandeira de Mello, op. cit., p. 207.

23 Almiro do Couto e Silva, "Poder Discricionário no Direito Administrativo Brasileiro", in: Revista de Direito Administrativo, Vol. 179. p. 57.

24 Em seu "Poder Discricionário e Ação Arbitrária da Administração", in: Problemas de Direito Público, Rio de Janeiro, Forense. 1960, p. 279. 
modo algum, pois o exercício da função administrativa orienta-se para a concretização normativa do texto legal, à revelação do interesse público nele contido para tomá-lo realidade. $\mathrm{O}$ ato administrativo está subordinado à lei, nele inexistindo espaço para a qualificação do interesse público contido no ato legislativo, do contrário, poderia licitamente o administrador fixar um interesse estranho, mesmo sendo de relevância coletiva, ao estabelecido em lei, $O$ que viola sem sombra de dúvida, os princípios da legalidade administrativa e da impessoalidade.

Deve ser lembrado ainda que apesar do interesse público não possuir um sentido inteiramente acabado na lei, sua concretização decorre do emprego do juizo de juridicidade, no âmbito da atividade administrativa. Quando se menciona a finalidade de um ato administrativo posto, refere-se ao resultado de um processo de densificação dos enunciados teleológicos da lei.

$\mathrm{O}$ motivo e o objeto constituem a residência natural da discricionariedade administrativa, quando admitida em lei ${ }^{25}$. Na dinâmica realidade na qual está inserida a administração pública, em se omitindo a lei, o juízo de oportunidade é imprescindível para garantir a proximidade entre a norma e o fato, a providência normativa e a demanda da coletividade, atribuindo-se ao administrador poder para selecionar os fatos enquadráveis na hipótese da lei, e para formar a avaliação político-jurídica que servirá de embasamento para o ato administrativo.

A oportunidade do ato é vinculada ao motivo, à identificação e formação dos pressupostos fáticos e jurídicos que justificam a inserção do ato administrativo no ordenamento jurídico. Já a conveniência incide sobre o objeto do ato, isto é, o conteúdo do provimento estatal.

Não há discricionariedade para a avaliação do motivo legal, pois trata-se de matéria restrita ao juízo de juridicidade. Será uma atividade de interpretação, e não discricionária, que fixará o pressuposto legal do ato administrativo. Portanto, embora o motivo fático possa constituir elemento discricionário, o motivo legal sempre será vinculado.

No conteúdo do ato administrativo, tem-se o uso do juízo de oportunidade pela administração pública ao se consolidar a conveniência, justiça e oportunidade da providência administrativa, na omissão da lei em fazê-lo. Mas a ausência da prescrição legal do objeto não implica em liberdade plena para sua fixação. $O$ objeto deve ser lícito e possível para a não rejeição do ato administrativo como ato jurídico válido. ${ }^{26}$.

E numa assertiva que se tornou clássica, Caio Tácito ${ }^{27}$ encerra tal questão:

"Não basta, porém, que a autoridade seja competente, o objeto lícito e os motivos adequados. A regra de competência não é um cheque em branco concedido ao administrador. A administração serve, necessariamente, a interesses públicos caracterizados. Não é lícito à autoridade servir-se de suas atribui-

25 Themistocles Brandão Cavalcanti, op. cit., p. 432.

26 Caio Tácito, "Abuso de Poder Administrativo no Brasil", cit., p. 51.

27 ldem, ibidem, p. 52 (grifo do autor). 
ções para satisfazer interesses pessoais, sectários ou político-partidários, ou mesmo a outro interesse público estranho à sua competência. A norma de direito atende a fins específicos que estão expressos ou implícitos em seu enunciado. A finalidade é, portanto, outra condição obrigatória de legalidade nos atos administrativos".

Tanto a discricionariedade quanto a vinculação não podem ser vistas numa visão absoluta. Compreendem elementos que devem existir em harmonia no regime jurídico-administrativo, sob pena de ou eliminar a criatividade e dinamismo indispensáveis à gestão dos interesses públicos, ou impossibilitar a fiscalização dos atos administrativos.

Embora haja forte resistência quanto ao emprego da expressão ${ }^{28}$, podemos conceituar o ato discricionário, no âmbito do regime jurídico-administrativo, como o ato administrativo que possui elementos construídos sob a influência do juízo de oportunidade do admiinistrador. Será ato vinculado o ato administrativo em que essa influência esteja restrita ao momento da sua expedição.

A ininterrupta torrente dos fatos trazidos à administração pública inviabiliza os esforços do legislador em produzir normas que cubram, de modo minucioso, todos os seus aspectos da ação administrativa. Faz-se então necessária a concessão de uma margem de liberdade decisória nos agentes e órgãos públicos para que estes possam apresentar as soluções exigidas pela lei e segundo sua finalidade maior, o interesse público $^{29} \mathrm{~A}$ interpretação nem sempre é suficiente para a concretização do regime jurídico-administrativo.

Nesses espaços abertos pela lei, a conveniência e a oportunidade para a prática do ato, a configuração do motivo do ato e o objeto a ser edificado no ato, tudo consoante a juridicidade, navega a discricionariedade. Compreende uma concessão legal ao Poder Público.

A norma jurídica que enseja a "opção discricionária", quando é confrontada com o caso concreto levado à apreciação da administração pública, tem suas imprecisões, "conceitos indeterminados", faculdades, concessões, proibições e soluções, propostas ou impostas, colocadas diante do administrador.

Perante o caso concreto, constitui dever irrenunciável ao agente ou órgão público apresentar as medidas cabíveis para a satisfação do interesse público, ou mesmo nenhuma em virtude deste. Tomada a decisão conforme a forma, competência e finalidades legais, em regra, é vedada a intervenção dos outros poderes do Estado no chamado "mérito do ato administrativo". A sua formação passa pela compreensão do conteúdo da norma jurídica a qual se atribui a cessão da discricionariedade.

28 Cf. Caio Tácito, "Desvio de Poder em Matéria Administrativa", in" Temas de Direito Público (Estudos e Pareceres), $1^{\circ}$ Vol., Rio de Janeiro, Renovar, 1997, p. 95; e Victor Nunes Leal, "Reconsideração do Tema do Abuso de Poder", in: Revista de Direito Administrativo, Seleção Histórica, pp. 457-458.

29 Themístocles Brandão Cavalcanti, op. cit., p. 433. 
O mérito do ato administrativo abrange um aspecto do procedimento da Administração, relacionado com circunstâncias e apreciações só perceptíveis ao administrador, dados os processos de indagação de que dispõe e a índole da função por ele exercida, vedado a incidência do controle jurisdicional ${ }^{30}$. $O$ mérito tem um sentido político, vinculado ao dever da boa administração, compreendendo todos os aspectos de conveniência e oportunidade edificados por um juízo comparativo na adequação da lei ao caso concreto". No processo civil, entende-se por mérito o "conteúdo substancial da lide"; enquanto que no direito administrativo, constitui um elemento que eventualmente pode compor $o$ ato administrativo. ${ }^{32}$

Inexiste mérito nos atos vinculados sendo elemento privativo dos atos discricionários $^{33}$. Nos atos vinculados, o juízo de oportunidade já foi analisado e definido pelo legislador, e, por conseguinte, inexistindo espaço para uma avaliação subjetiva de conveniência e oportunidade da ação estatal no caso concreto ${ }^{34}$.

A conveniência e a oportunidade são os elementos utilizados na técnica discricionariedade na formação do mérito, seu resultado final, a fim de satisfazer um interesse público específico contido no texto normativo. Enfim, a discricionariedade define os aspectos que devem ser deixados ao juízo de oportunidade da administração, passando o mérito a conter todos os aspectos edificados pelo binômio conveniência-oportunidade ${ }^{35}$.

O mesmo não acontece no proceso administrativo, onde o mérito tem sentido similar a do processo civil, ou seja, o conteúdo da lide, como entende José Cretella Júnior $^{36}$. $\mathrm{O}$ mérito do processo administrativo está sujeito a amplo exame judicial ${ }^{37}$.

A competência poderá estatuir que, dentre vários atos legalmente possíveis, "tenha o administrador a faculdade de escolher aquele que julgue mais conveniente e oportuno, bem como de determinar a feição concreta que o ato deverá ter" ${ }^{38}$.

O poder de escolha está relacionado com o "se" e o "como" da ação administrativa ou com ambos ${ }^{39}$. O poder discricionário sempre se manifesta no âmbito da consequiência jurídica, existindo uma forma de poder discricionário que se identifica na decisão relativa à adoção ou não de uma medida determinada; e outra, que se refere apenas com a escolha do ato a ser praticado, dentre as alternativas cabíveis. ${ }^{40}$

30 Miguel Seabra Fagundes. "Conceito de Mérito no Direito Administrativo", Revista de Direito Administrativo. Seleção Histórica, p. 189.

31 Idem, ibidem, p. 190. Cf. José Cretella Jünior, op. cit., pp. 72-75.

32 Miguel Seabra Fagundes, op. cit., p. 193.

33 Em sentido contrário: José Cretella Júnior, op. cit., pp. 78-79.

34 Miguel Seabra Fagundes, op. cit., p. 194.

35 Diogo de Figueiredo Moreira Neto, Legitimidade e Discricionariedade, 2 ed. Rio de Janeiro, Forense, 1991, p. 32.

36 Op. cit., p. 66.

37 Idem.

38 Almiro do Couto e Silva, op. cit., p. 48.

39 Idem, ibidem, p. 55.

40 Idem, ibidem, p. 48. 


\section{O Problema dos "conceitos jurídicos indeterminados"}

Um ponto de controvérsia que se verifica no estudo do poder discricionário é o concernente à sua relação com os "conceitos jurídicos indeterminados" e, por conseguinte, ao estabelecimento de uma zona de livre apreciação no exercício da atividade administrativa e segundo os limites da lei.

José Eduardo Faria ${ }^{41}$ define-os do seguinte modo (embora esteja se referindo o que denominamos termos):

“Os 'conceitos jurídicos indeterminados' são expressões propositadamente vagas utilizadas pragmaticamente pelo legislador com a finalidade de propiciar o ajuste de certas normas a uma realidade cambiante ou ainda pouco conhecida; graças a esses conceitos, o intérprete pode adequar a legislação às condições sócio-econômicas, políticas e culturais que envolvem o caso concreto e condicionam a aplicação da lei".

Expressam e qualificam as necessidades públicas cuja satisfação representa o destino da administração pública. Tais como "utilidade pública", "urgência”, "grave comoção", "relevância" etc.

A palavra é um veículo do pensamento que sofre com as limitações da linguagem. Ela é insuficiente, por si só, de revelar o conteúdo da lei, sendo imprescindível a ação do operador jurídico para lhe fixar o sentido e alcance de seu emprego em dado documento legal ${ }^{42}$. Se o texto normativo não se confunde com a norma, embora aquele seja o ponto de partida deste, o conceito jurídico não se confunde com o termo empregado para designar um ou mais valores, um ou mais fatos da realidade social que se deseja juridicamente regular, pois o conceito é produto da reflexão que expressa uma suma de idéias sobre algo ${ }^{43}$.

Dentro da concepção essencialista de língua, esta seria capaz de designar a realidade, delimitando com precisão o objeto que se descreve ${ }^{44}$. Contraposta a tal entendimento, a concepção convencionalista vê a língua como: “(...) um sistema de signos, cuja relação com a realidade é estabelecida arbitrariamente pelos homens (...) o que deve ser levado em conta é o uso (social ou técnico) dos conceitos que podem variar de comunidade para comunidade (...)", consoante o critério vigente para designar a palavra na situação social concreta ${ }^{45}$. Esta última tem um alcance prático mais satisfatório que a primeira, haja vista a dificuldade de se propor conceitos genéricos e universais que possam abranger todas os casos específicos ${ }^{46}$. $\mathrm{O}$

41 Em seu Direito e Economia na Democratização Brasileira. São Paulo, Malheiros, 1993, p. 139.

42 Carlos Maximiliano. Hermenêutica e Aplicação do Direiro, 14 ed. rio de Janeiro, Forense, 1994, p. 36.

43 Eros Roberto Grau, "Crítica da Discricionariedade e Restauração da Legalidade", in: Direito Posto e Direito Pressuposto, São Paulo, Malheiros. 1996, pp. 143-145.

44 Tércio Sampaio Ferraz Júnior, Introdução ao Estudo do Direito, 2 ed., São Paulo, Atlas, 1994, p. 34.

45 Idem, ibidem, pp. 35-36.

46 Idem, ibidem, pp. 34 e 36. 
sentido e o alcance da palavra, portanto, variará segundo a situação social na qual se insere e, bem como, o seu modo de emprego para descrevê-la ou modificá-la ${ }^{47}$.

Por ser vago e impreciso, o termo indeterminado enseja o surgimento de conceitos diversos. Uns são conceitos empíricos, referindo-se a fatos, situações ou estados da natureza ou da realidade (ruído, dia, óbito, por exemplo); outros são conceitos valorativos, sendo exigido do hermeneuta jurídico a sua apreciação consoante as peculiaridades destes (conduta desonrosa, motivo torpe, segurança nacional, por exemplo) ${ }^{48}$

O sentido e o alcance do termo empregado é construído através da aplicação. Nenhum termo legal é claro per si, mas chega a objetividade quando há intervenção, do juiz ou do administrador. O velho brocardo in claris cessat interpretatio não pode mais ser aceito, pois a interpretação é fase anterior a toda formulação da norma jurídica e da norma de decisão, inclusive e principalmente na discicionariedade.

Carlos Maximiliano ${ }^{49}$ levanta com nitidez a questão:

"Que é lei clara? É aquela cujo sentido é expresso pela letra do texto. Para saber se isto acontece, é força procurar e conhecer o sentido, isto é, interpretar. A verificação da clareza, portanto ao invés de dispensar a exegese implica-a, pressupõe o uso preliminar da mesma. Para se concluir que não existe atrás de um texto claro uma intenção efetiva e desnaturada por expressões impróprias, é necessário realizar prévio labor interpretativo".

Os conceitos jurídicos são conceitos convencionalistas, através dos quais o jurista procura estabelecer padrões de conduta para a sociedade. É impossível a lei tudo prever e tudo alcançar e, por isso, emprega quem a edita termos dotados da necessária fluidez, preservando a flexibilidade do sistema direito positivo perante a naturalmente instável realidade social. Será o labor interpretativo o veículo para dar vida e objetividade aos enunciados do direito positivo, que ganham maior certeza e segurança quando há a concretização normativa do texto legal.

Seu objeto é a significação atribuível a uma coisa, estado ou situação, e não a coisa, estado ou situação em si, nas palavras de Eros Roberto Grau ${ }^{50}$. Essa significação precisa ter um mínimo de determinação e uniformidade para que ele tenha utilidade, ou seja, conceda e viabilize um mínimo de segurança e certeza na aplicação do direito ${ }^{5}$. Do contrário, o conceito traz muito mais problemas do que soluções para as demandas jurídicas.

Não é o conceito jurídico indeterminado ou fluido. O termo do texto normativo é que será mais ou menos fluido, dependendo da dificuldade de seu desvelamento pela via interpretativa. Se o termo empregado pelo legislador é indeterminado, cabe

47 Friedrich Müller, Direito - Linguagem - Violência: Elementos para uma Teoria Constitucional, I, Porto Alegre, Sérgio Antônio Fabris Editor, 1995, p. 36.

48 Almiro do Couto e Silva, op. cit., p. 58.

49 Op. cit., p. 38 (grifo no original).

50 Op. cit., p. 146.

51 Idem, ibiden, p. 144. 
ao aplicador do direito fixar seu sentido e alcance, determinando- $0^{52}$, pelo menos no caso concreto.

Os termos da lei podem ou não exigir maior trabalho de intérprete, mas este sempre existirás ${ }^{53}$.

Pode haver, então. espaço para uma única solução justa, mesmo na interpretação e concretização do exposto no termo indeterminado da lei, se assim o caso concreto orientar. Só teremos discricionariedade quando o texto normativo se permitir duas ou mais soluções justas, e, consequientemente, abrindo espaço para a apreciação subjetiva do administrador. Mas, em todo e qualquer caso concreto, o "conceito jurídico indeterminado" se torna determinável:

"Pero al estar refiriéndose a supuestos concretos y no a vaguedades imprecisas o contradictorias, es claro eu la aplicación de tales conceptos o la calificación de circunstancias concretas no admite más que una solución: o se da o no se da el concepto; o hay buena fe o na la hay; o el precio es justo o no lo es; o se há faltado a la probidad o no se há faltado. Tertium non datur. Esto es lo essencial del concepto jurídico indeterminado: la indeterminación del enunciado no se traduce en una indeterminación de las aplicaciones del mismo, las cuales sólo permitem una 'unidad de solución justa' en cada caso" 54 .

Há grande dificuldade na descoberta da solução exata no direito ${ }^{55}$, prevalecendo sim, um elenco de soluçōes corretas para o caso concreto ${ }^{56}$. Essas opções não serão submetidas ao juízo de oportunidade do administrador, no campo do regime jurídico-administrativo. A ponderação dos termos legais, fluidos ou não, é subordinada ao juízo de juridicidade do administrador, que deve escolher a mais adequada para ordenamento jurídico e a mais conciliada com as exigências do caso concreto. $O$ dever de eficiência na discricionariedade administrativa não se reduz ao juizo de oportunidade ${ }^{57}$.

E como afirma Celso Luiz Moresco ${ }^{98}$ :

“(...) a utilização de termos elásticos ou imprecisos não é sinônimo de autorização para tomada de qualquer decisão ou seja, não significa que qualquer decisão tomada dentro de seus limites seja válida".

Nesse elenco de opçōes jurídicas, a escolha do administrador pode ou nāo ser alterada pelo Poder Judiciário. Se cabe ao órgão jurisdicional encerrar o processo

52 ldem, ibidem, pp. 146-148.

53 Carlos Maximiliano, op. cit., pp. 37-38.

54 Eduardo Gárcia de Enterría \& Tomás-Ramón Fernandez, op. cit., p. 449.

55 Eros Roberto Grau, op. cit., pp. 149-150.

56 Celso Antônio Bandeira de Mello, Discricionariedade Administrativa e Controle Jurisdicional, cii, p. 23.

57 É certo que a eficiência administrativa ajuda a compor o juízo de juridicidade presente no processo discricionário. Mas o controle jurisdicional dessa juridicidade, sob a ótica estrita da eficiência é bastante problemática.

58 Em seu "Conceitos Jurídicos Indeterminados", in: Revista Trimestral de Direito Público, N 14/1996, p. 84. 
de concretização normativa do texto legal, o juízo de juridicidade do juiz acaba por prevalecer sobre o juízo de juridicidade do administrador, se aquele constatar que a solução jurídica escolhida por este é rejeitada pelo ordenamento jurídico.

Com uma importância ressalva: a interpretação do texto legal nem sempre (ou quase) é suficiente para fixar a melhor solução para o caso concreto. Uma coisa é interpretar o texto legal, e outra, é interpretar o texto legal em conjunto com os elementos do caso concreto.

Ao controlar a concretização de textos normativos que utilizam termos fluidos ou indeterminados, deve o Poder Judiciário estabelecer zonas de definição em torno do conceito jurídico, quando ele inspirou uma providência administrativa.

Haverá uma zona de certeza positiva, que conterá as soluções juridicamente corretas e aceitáveis; uma zona de certeza negativa, que abrangerá as soluções juridicamente repelidas; e uma zona intermediária, cinzenta, entre a positiva e a negativa, composta pelas soluções que guardam controvérsias sobre sua viabilidade jurídica.

Quando provocado para apreciar um ato administrativo dotado de mérito, o órgão jurisdicional revisará o juízo de juridicidade empregado pelo administrador, somente apreciando o seu juízo de oportunidade quando imprescindível para a verificação de sua compatibilidade para com a ordem jurídica. Se o conceito jurídico baseado em termos fluidos é subordinado ao juízo de juridicidade do administrador, e este, necessariamente, submete-se à revisão judicial quando há indício de atentado à ordem jurídica, não pode o Poder Judiciário deixar de invalidar da discricionariedade se esse for constatado.

$\mathrm{O}$ "conceito jurídico indeterminado" não pode ser enquadrado, por conseguinte, como fonte necessária do poder discricionário, ainda que este não esteja sujeito a um controle judicial pleno, por ser inviável ao Poder Judiciário declarar a inteira correção ou o total equívoco do comportamento administrativo". No caso dos "conceitos jurídicos indeterminados", há a plenitude do controle jurisdicional, "só esbarrando na fronteira da impossibilidade cognitiva de declarar se a aplicação foi correta ou equivocda" 60 .

A complexidade do ato concreto e a diversidade de opiniões e pareceres constituem os limites eu impedem ao julgador alterar a decisão administrativa, quando no exame da aplicação de "conceitos jurídicos indeterminados" pela administração pública. No exercício do dever-poder discricionário, a lei toma para si a demarcação das fronteiras proibidas à revisão judicial dos atos administrativos, que por sua vez, compreendem a "área de apreciação" do administrador.

Quando confrontado com a realidade fática, dispõe o administrador também de uma margem de liberdade intelectiva pois, afinal, ele também é um aplicador do direito. É admissível ao agente público produzir um ato portador de mérito em razão de ter sido adotado um comportamento administrativo aceitável para o caso concreto.

59 Almiro do Couto e Silva, op. cit., p. 59.

60 Idem, ibidem, p. 60. Cf. Celso Antônio Bandeira de Mello. Discricionariedade Administrativa e Controle Jurisdicional. São Paulo, Malheiros, 1992, pp. 42-43. 
Comportamento este que pode ser extraído do "conceito legal fluido", e, insusceptível de correção judicial, se a interpretação se mostrar insegura, ou seja, se o órgão jurisdicional não logrou êxito em retirar a solução escolhida pela administração pública da zona cinzenta de definição, ou verificar que ela permaneceu na sua zona positiva.

Cabe ao Poder Judiciário verificar se houve a violação ao direito, devendo verificar se a administração pública ficou dentro do "campo significativo da aplicação" do conceito normativo vago ou se foi desconhecido. Deve ainda reconhecer se a decisão administrativa é incensurável e a ausência de direito subjetivo de terceiro ameaçado ilegalmente pelo comportamento administrativo adotado.

A discricionariedade administrativa é integrada tanto pelo juízo de oportunidade como pelo juízo de juridicidade. Afinal, se a discrionariedade é um processo jurídico de decisão, é impossível que seja constituído apenas pelo juízo de oportunidade. É na arbitrariedade que o juízo de juridicidade é ausente. Como bem leciona Themístocles Brandão Cavalcanti ${ }^{61}$ :

"o exercício dêsse poder é apenas um processo técnico para definir a interpretação da lei e a maneira mais adequada de aplicá-la. É uma parte e não a totalidade da ação administrativa ou política".

Todavia, somente após o esgotamento da interpretação fica aberto o espaço para a aplicação do juízo de oportunidade, para a apreciação política do caso concreto e a seleção das soluções jurídicas mais convenientes e oportunas. Discricionariedade e interpretação são duas noções distintas, mas não há apreciação de conveniência e oportunidade sem a antecedência da seleção da norma jurídico-administrativa aplicável ao caso concreto. Se considerarmos a interpretação como uma fase exterior à discricionariedade, estaremos admitindo que possa haver um processo de decisão no Estado de Direito onde o juízo de juridicidade está inteiramente ausente, impossibilitando a própria intervenção judicial na ação administrativa quando o ato administrativo portador de mérito contém vício que não se revela pelo que foi formalmente exteriorizado.

Por conseguinte, a discricionariedade administrativa é um processo cuja a primeira fase é justamente a interpretação. Se a interpretação não leva a segurança jurídica necessária sobre a solução aplicável ao caso concreto. permite-se ao administrador identifique e concretize as opções políticas do sistema de direito positivo através da apreciação da conveniência e oportunidade da medida administrativa requerida ou necessária. A norma jurídica também tem função e conteúdo políticos.

Não se pode negar que, na edição de uma lei pelo Congresso Nacional ou em sua concretização final mediante um ato administrativo portador de mérito, há apreciação política da realidade social. O sistema jurídico não é impermeável à influência do sistema político, desde que esta não comprometa dos processos funcionais do sistema de direito positivo. A discricionariedade é, sem sombra de dúvida, 
um canal de cognição que o sistema jurídico cria com o sistema político, através do qual o aplicador do direito positivo identifica as opções políticas da ordem jurídica e as confronta com a realidade social. Mas não cabe ao legislador ou ao administrador modificar os valores juridicizados pela Constituição através da discricionariedade. Compreender a ideologia da norma não é corrompê-la.

Tanto o juízo de juridicidade como o juízo de oportunidade têm conseqüências jurídicas, chegando inclusive a se mesclarem e, tornando prejudicial ao controle judicial da medida administrativa, a sua dissociação. A juridicidade e a oportunidade, no exercício do dever-poder discricionário pela administração pública, nem sempre apresentam fronteiras nítidas. Somente em ficção, podemos acreditar que, quando há diversidade e controvérsia na intelecção do direito positivo, a escolha do administrador não está direta e irremediavelmente ligada a sua apreciação política da realidade dos fatos jurídicos-administrativos.

$\mathrm{Na}$ discricionariedade administrativa, o juizo de oportunidade integra politicamente o regime juridico-administrativo quando o juizo de juridicidade é insuficiente para revelar a melhor solução para o caso concreto. $\mathrm{O}$ administrado não pode esperar que a ciência do direito solucione controvérsia para que a administração pública exerça suas atribuições. Portanto, o controle judicial efetuado sobre esses elementos tem intensidade e natureza diferenciadas pois, "a discricionariedade ensejada pela fluidez significativa do pressuposto ou da finalidade da norma cingir-se-á sempre ao campo de insolúveis dúvidas sobre o cabimento dos conceitos utilizados pela regra de direito aplicado" 62

A função administrativa não pode ser reduzida à mecânica tradução em ato de imperativos legais pois de outro modo, comprometer-se-ia a proteção e a garantia dos direitos individuais, a separação funcional do poder e o princípio da superioridade da lei material e formal em relação às outras funções estatais, sendo hoje impossível a sua total submissão ao controle jurisdicional. Administrador tímido é tão prejudicial quanto administrador arbitrário.

O órgão legislativo institui as diretivas da atividade administrativa através de comandos para os órgãos ou agentes da administração pública. São acrescentados aos limites naturais e lógicos que regulam a atividade administrativa as condições de aplicação da norma, estabelecendo uma ação, negativa ou positiva, da qual não se pode eximir a administração pública.

Inexiste no direito público, que rege a administração pública, o princípio da autonomia da vontade. Cabe ao agente público, dentro da parcela da sua competência, identificar na realidade as condições de fato previstas na norma administrativa, conforme a finalidade legal. Mas a vontade do administrador se torna relevante, por força de lei, na discricionariedade administrativa. A administração pública precisa de espaço, de instrumentos que assegurem a dinâmica e a iniciativa do administrador, desde que subordinados, evidentemente, aos princípios e regras do regime jurídicoadministrativo. 
O texto normativo aponta as situações de fato que compreenderão as condições de imputabilidade de qualquer ato à administração pública ${ }^{63}$. Perante as condições de fato, competirá ao agente desenvolver de início, um processo interpretativo, circunscrito à liberdade que a lei lhe conferiu, defrontando-se com duas espécies terminológicas e conceituais: conceitos de significação definível e conceitos de significação exata indeterminada ou plurissubjetivos ${ }^{64}$. Logo o Estado de Direito impõe um limite para a determinação dos conceitos utilizados na norma ao legislador, sob pena de se passar da norma abstrata à ordem individualizada ${ }^{65}$

Nesses "conceitos plurissubjetivos", a interpretação teria se mostrado falha para a revelação completa da melhor solução jurídica para a demanda da administração pública, fazendo-se necessário superar a insegurança da hermenêutica pela concessão e reconhecimento de força jurígena ao juízo de oportunidade do administrador. Assim não entende Almiro do Coutro e Silva ${ }^{66}$, pois apesar de que, na sua ótica, a impossibilidade da consolidação de um só entendimento junto aos "conceitos jurídicos indeterminados" inviabilize a apreciação jurisdicional, a matéria não deixaria de ser referente à juridicidade. Na sua visão, malgrado inexistir limites legais para a apreciação jurisdicional da aplicação correta dos "conceitos jurídicos indeterminados", existiria tal obstáculo, de ordem hermenêutica, para tanto.

No caso do poder discricionário, o controle jurisdicional de atos administrativos "está, a priori, limitado pela lei, a qual fixou desde logo as linhas dentro das quais poderá a autoridade administrativa livremente tomar suas decisões. Dentro daquele espaço, qualquer uma delas será juridicamente incensurável e inexaminável pela autoridade judiciária" ${ }^{67}$. Para esse jurista, se a norma contiver conexão entre "conceito jurídico indeterminado" e poder discricionário, dever o intérprete separá-los e tratá-los de forma distinta ${ }^{68}$.

A nosso ver, quando o Poder Judiciário se depara com a impossibilidade material de fixar a aplicação mais correta do "conceito jurídico indeterminado", é quase sempre impossível identificar a fronteira entre o juízo de oportunidade e o juízo de juridicidade, pois aí, houve justamente a perigosa mistura de ambos. Se o Poder Judiciário pudesse dissociar os elementos de juridicidade dos elementos de oportunidade na ação administrativa, haveria, sem sombra de dúvida, espaço para um controle total, sob a ótica da juridicidade. Aqui, o Poder Judiciário não pode se imiscuir na opção hermenêutica do Poder Executivo por lhe ser impossível fixar a opção mais correta, que afaste por completo e de modo inquestionável outros caminhos interpretativos, já que, do contrário, haveria a substituição do juízo de oportu-

63 Afonso Rodrigues Queiró, “A Teoria do Desvio de Poder do Direito Administrativo”, in: Revista de Direito Administrativo, $\mathrm{n}^{\circ}$ 6, p. 56.

64 Idem.

65 Afonso Rodrigues Queiró, “A Teoria do Desvio de Poder do Direito Administrativo”, cit., p. 57.

66 Op. cit., p. 60.

67 Idem.

68 Ibidem. 
nidade jurisdicional que, como vimos, tem difícil existência no ordenamento jurídico dos países regidos pelo princípio da separação funcional do Poder.

Quando previstas de modo incontrastável as premissas de fato na norma, segue a administração na prática dos atos que estabelece diante da constatação daquelas ${ }^{69}$. Se, ao invés, essas premissas são previstas em forma constrastável, será necessário que o agente estabeleça o conceito oriundo de uma das várias interpretações possíveis $^{70}$. A discricionariedade possibilita e garante, conseqüentemente, a aplicabilidade da norma jurídica.

O problema do poder discricionário também é um problema de interpretação ${ }^{71}$. A norma jurídica impõe como dever a administração pública uma determinada atividade que este fica obrigado a realizar, sempre que no mundo das realidades um certo fato ou condições se verifiquem. Apresentam-se como conceitos, que podem pertencer ao mundo da realidade empírica, indubitavelmente individualizados, embora abstratos, ou no mundo da realidade contraposta, onde predomina a incerteza. Nesta, caberá ao agente administrativo fazer a subsunção dos fatos aos conceitos postos e interpretáveis, segundo o que estritamente a competência que ensejou a discricionariedade administrativa permitir.

Isso não significa dizer que o juízo de oportunidade possa prevalecer sobre o juízo de juridicidade. No Estado de Direito, os critérios de conveniência e oportunidade devem estar necessariamente submetidas à análise de sua compatibilidade para com o direito positivo. Se o órgão controlador, mesmo sendo de natureza jurisdicional, verifica que houve a violação ideológica da lei, nada impede, numa perspectiva dogmática, a invalidação judicial do ato administrativo portador de mérito. No caso do controle judicial da moralidade administrativa, por exemplo, a análise do órgão jurisdicional afere se o juízo de oportunidade empregado pelo administrador se ateve ou não ao cânone constitucional, perdendo o mérito sua imunidade, a nosso $\mathrm{ver}^{72}$

\section{Considerações finais}

A questão da discricionariedade na ação administrativa constitui um dos pontos centrais da preocupação dos estudiosos do direito administrativo. Manifesta-se o fenômeno da discricionariedade administrativa quando:

a) a lei expressamente confere ao administrador a faculdade de optar por uma dentre as soluções jurídicas pela mesma apontadas no caso da ocorrência da situação fática nela descrita;

69 Idem.

70 Afonso Rodrigues Queiró, op. cit., p. 58.

71 ldem, ibidem, p. 64.

72 Cf. Vladimir da Rocha França, "Considerações sobre o Controle da Moralidade dos Atos Administrativos", in: Revista da ESMAPE. Vol. 3. n 8. pp. 434-437. 
b) deixa a lei de apontar o motivo ou o objeto do ato administrativo, elementos essenciais para sua constituição;

c) quando a lei emprega "conceitos jurídicos indeterminados" e, se e somente se, for materialmente impossível para o Poder Judiciário fixar a melhor interpretação para a situação jurídica posta sob sua apreciação.

Essa última assertiva não deve ser encarada como admissão do "conceito jurídico indeterminado" como "fonte" da discricionariedade administrativa. Não se trata disto.

A discricionariedade administrativa é um processo jurídico-político de decisão, onde há a inserção controlada de elementos metassistêmicos - juridicização do político - no ordenamento jurídico, por injunção da volátil realidade social que a administração pública deve encarar. Se a interpretação, fase que the é primeira e onipresente, se mostra insuficiente para o deslinde semântico da norma diante do caso concreto, surge então espaço para que o administrador empregue um juízo de oportunidade para a resolução do que lhe foi requerido ou concretização da finalidade que the foi imputda. Posteriormente, o mérito é sujeito ao controle interno da própria administração pública e ao controle jurisdicional, este se invocado, relacionando-o com a ideológica constitucional (em especial, sob a ótica dos princípios da isonomia e da moralidade administrativa $)^{73}$.

Em suma: o "conceito jurídico indeterminado" não é origem necessária da discricionariedade, mas tão-somente um elemento que, quando em conjunto com os limites de sua interpretação e os dados do caso concreto, contribui para que o sistema jurídico não deixe outra opção para o administrador senão recorrer ao seu juízo de oportunidade.

Assim, esperamos ter contribuído, de algum modo, para a compreensão de capítulo tão importante na teoria dos atos administrativos.

\section{Referências bibliográficas}

CAVALCANTI, Themístocles Brandão. "Do Poder Discricionário". in: Revista de Direito Administrativo. Seleção Histórica: 431-451, 1991.

CRETELLA JÚNIOR, José. O "Desvio de Poder" na Administração Pública. 4 ed. Rio de Janeiro: Forense, 1997.

ENTERRÍA, Eduardo Garcia \& Tomás. Ramón Fernandez. Curso de Derecho Administrativo - I. 8 ed. Vol. I Madrid: Civitas, 1998.

FERRAZ JÚNIOR, Tércio Sampaio. Introdução ao Estudo do Direito. $2^{a}$ ed. São Paulo: Atlas, 1994.

FARIA, José Eduardo. Direito e Economia na Democratização Brasileira. São Paulo: Malheiros, 1993.

73 Para uma defesa da admissibilidade do controle judicial de mérito, ver Invalidação Judicial da Discricionariedade Administrativa. Recife, 1998, pp. 141-153. 
FRANÇA, Vladimir da Rocha. Invalidação Judicial da Discricionariedade Administrativa. Recife: 1998, p. 176. Dissertação (Mestrado em Direito Público) Universidade Federal de Pernambuco.

"Considerações sobre o Controle da Moralidade dos Atos Administrativos". in: Revista da ESMAPE. Vol. 3, n 8: 403-440.

GRAU, Eros Roberto. "Crítica da Discricionariedade e Restauração da Legalidade". in: O Direito Posto e o Direito Pressuposto. São Paulo: Malheiros, 1996: 140166.

LEAL, Victor Nunes. "Poder Discricionário e Ação Arbitrária da Administração". in: Problemas de Direito Público. Rio de Janeiro: Forense, 1960: 278-294.

MAXIMILIANO, Carlos. Hermenêutica e Aplicação do Direito. 14a ed. Rio de Janeiro: Forense, 1994.

MEIRELLES, Hely Lopes. Direito Administrativo Brasileiro. $20^{\mathrm{a}}$ ed. atual. por Eurico de Andrade Azevedo et al. São Paulo, Malheiros, 1995.

MELLO, Celso Antônio Bandeira de. Discricionariedade e Controle Jurisdicional. São Paulo: Malheiros, 1992.

. Curso de Direito Administrativo. 5a ed. São Paulo: Malheiros, 1994.

MOREIRA NETO, Diogo de Figueiredo. Legitimidade e Discricionariedade. $2^{\mathrm{a}} \mathrm{ed}$. Rio de Janeiro: Forense, 1991.

MÜLLER, Friedrich. Direito - Linguagem - Violência. Elementos de uma Teoria Constitucional - I. Porto Alegre: Sérgio Antônio Fabris Editor, 1995.

NEVES, Marcelo. A Constitucionalização Simbólica. São Paulo: Acadêmica, 1994. QUEIRÓ, Afonso Rodrigues. “A Teoria do Desvio de Poder do Direito Administrativo". In: Revista de Direito Administrativo. $\mathrm{n}^{\circ}$ 6: 41-78.

SEABRA FAGUNDES, Miguel. O Controle dos Atos Administrativos pelo Poder Judiciário. 6 ed. São Paulo: Saraiva, 1984.

"Conceito de Mérito no Direito Administrativo". in: Revista de Direito Administrativo. Seleção Histórica: 18-203.

SILVA, Almiro do Couto e "Poder Discricionário no Direito Administrativo Brasileiro". In: Revista de Direito Administrativo. $\mathrm{n}^{\circ}$ 179: 51-67.

TÁCITO, Caio. "Abuso de Poder Administrativo no Brasil". in: Temas de Direito Público (Estudos e Pareceres). $1^{\circ}$ Vol. Rio de Janeiro: Renovar, 1997: 39-70.

"Desvio de Poder em Matéria Administrativa". in: Temas de Direito Público (Estudos e Pareceres). $1^{\circ}$ Vol. Rio de Janeiro: Renovar. 197: 71-159.

"Ato e Fato Administrativo". in: Temas de Direito Público (Estudos e Pareceres). $1^{\circ}$ Vol. Rio de Janeiro: Renovar, 1997: 297-307.

ZANCANER, Weida. Da Convalidação e da Invalidação dos Atos Administrativos. $2^{a}$ ed. São Paulo: Malheiros, 1993. 